\title{
Examination of Moral Decision-making Attitudes of Elite Male Basketball Players and Wrestlers According to Variables of Sport Experience and Mother, Father Education ${ }^{i}$
}

\author{
Fethi Arslan", ${ }^{1, *}$, Mehmet Akif Ziyagil ${ }^{1,2}$, Canan Bastık $^{3}$ \\ ${ }^{1}$ School of Physical Education and Sports, Mersin University, Turkey \\ ${ }^{2}$ Giresun University, Turkey \\ ${ }^{3}$ Department of Physical Education and Bursa, Bursa Technical University, Turkey
}

Copyright $\bigcirc 2018$ by authors, all rights reserved. Authors agree that this article remains permanently open access under the terms of the Creative Commons Attribution License 4.0 International License

\begin{abstract}
The purpose of this research was to examine the extent to which at sport moral decision making attitudes were applied by the athletes, and the factors that caused it. The research was based on the causal comparative research model. The research group consisted of a total of 475 athletes, of which 195 were basketball athletes randomly selected from seven geographical regions and 280 were wrestling athletes. Lee, Whitehead, \& Ntoumanis [23] used data collection tools to measure the moral decision-making attitudes of athletes (Attitude Moral Decision Making in Youth Sport Questionnaire AMDYSQ). Gürpınar [16] has adapted the "Moral Decision Making Attitudes Scale in Infrastructure Sports" to Turkish culture. Mann Whitney-U test was used in binary comparisons because data were not normally distributed. As a result of the research, Significant differences were found according to subscales of Moral decision-making attitudes in infrastructure sports, such as wrestling and basketball, according to the subscale of adopting competition affinity, cheating, and winning fairness. In individual and team sports, it can be said that the athletic experiences are firstly influenced by the educational level of the parents after the athletes gain moral behaviors. The results of the research were supported by the literature.
\end{abstract}

Keywords Basketball Education, Wrestling Education; Moral Decision Makings

\section{Introduction}

Sports is a cultural phenomenon that develops the abilities of individuals, that can be performed by means or no means in the framework of certain rules for leisure time or competition with its social, spiritual, physical as well as mental effects on human beings Erkal, Güven \&Ayan [10]. Although there was agreement related to sports participation in that it builds moral character and fosters moral functioning Shields \& Bredemeier [31], several anti-social behaviors including doping, foul play, injuring an opponent, aggression, cheating and gamesmanship are observed in most of sport situations. Despite these immoral or etically inappropriate behaviors, it has been believed that positive behavior, values and desirable personal characteristics for all can be accomplished through the true orientation of sports practice Cruz, Capdevila, Boixadós, Pintanel, Alonso, Mimbrero, \& Torregrosa [7]; Roig \&Ballew [30]; Lee, Whitehead, Ntoumanis, \& Hatzigeorgiadis [24]. In addition, being successful and superior always attract and excite people desiring to sense this feeling in every area of life and to obtain some financial gain [34]. The individual is highly motivated because of increased external motives on his success feeling and he/she can exhibit aggressive and attitudes resulted in his/her immoral (non-moral) behavior. However, the borders of aggression and behavior in sport activities are determined by the intention and deliberateness of movement with the rules of the sport concerned. Attitude of conduct that is perceived as an aggression and behavior in daily life can be regarded as a natural behavior within the framework of the rules within a sporting event [21]. Although it is believed that the gentlemanliness is the base of sport in the society, it is clear that most of the behaviors displayed in sporting environments are out of sportsmanship [25]. The athlete, coach, manager, referee and spectator should be honest, 
Moral, virtuous, respectful and tolerant in the discipline and must respect the rules and others in and out of sport fields and halls, [25, 37]. The athletic students' moral decision-making attitudes depend on a variety of factors such as education level, gender, duration of sportive experience, and sport branch [35, 9, 14, 23, 19, 22, 29, 16]. In this context, sport as an educational tool is being used by all segments of the society.

It is possible to get as much positive output from sports by adhering to the sporting ethics, philosophical principles and rules [28]. Adopting the cultural and moral values accepted in the society by the individuals will enable the existence of healthy societies to fulfill the duties and responsibilities expected from the society in which the individual lives [15]. However; there are some researchers that hand reported a positive relationship between sport participation and delinquency [13]. On the other hand, Begg, Langley, Moffitt, Marshall [3] show that increasing guilt is not about team sports but about individual sports.

Gürpınar [16] demonstrated moral decision making scores are higher in girls than boys; secondary school students than high school students; noncontact sports than contact sports and inexperienced student athletes than experienced student athletes. In addition, the attitudes to moral decision making were differentiated among sports branches. The Moral behaviors were accepting from athlete, coach, manager, referee and spectator in daily life of sport fields and halls [37]. Measuring and evaluating the athletic attitudes of the athletes has attracted considerable attention from researchers since the mid 80 's. It is important to compare the moral decision-making behaviors of the individual athletes with the team athletes in which the team is chest to chest, and the effect of the individual and the group struggle. This study aims to compare the Moral decision-making levels of young athletes and to reveal the perception level of sport morality.

\section{Method}

In the method part of the research, the model of the researcher, the research group, the data collection tools used, the data collection process, the analysis of the data, the information about the research and the explanations will be given.

\section{Research Models}

This research was conducted with a causal comparative research model in which the wrestling and basketball athletes' attitudes towards moral decision-making were examined by the athletes and the factors that caused it. In an existing situation, relations between variables are examined in terms of cause and effect, $[4,11,5]$. By means of this research method, it was aimed to evaluate the effectiveness of different variables by measuring the research group. Therefore, Causal Comparative model, a sub-dimension of relational research model, is used.

\section{Research Group}

The research group was determined by the "non-arbitrary" sampling method. The study group consisted of seven regions (Marmara Region 97\% (20.4\%), Black Sea Region 46 (9.7\%), Ege Region 96 (20.2\%), Central Anatolia Region 85 (17.9\%), Mediterranean Region 80 (16.8\%), Eastern Anatolia Region 21(4.4\%), and South Eastern Anatolia Region 50 (10.5\%).

A total of 475 (100\%) athletes, including 195 (41.1\%) basketball athletes and $280(58.9 \%)$ wrestling athletes were selected by chance, $371(78.1 \%)$ athletes have between 1-10 years, 104 (21.9\%) athletes have between 11-20 years of sports experience. $413(86.9 \%)$ of these athletes have high school and below, 62 (13.1\%) have undergraduate and graduate education levels. In the father education level, 391 $(82.3 \%)$ have undergraduate and graduate father education levels, while $84(17.7 \%)$ have high school and below.

\section{Data Collection Tool}

The Moral Decision-Making Attitudes Scale for Infrastructure Sportsmen: The scale of Attitudes Moral Decision-Making in Youth Sport Questionnaire (AMDYSQ) developed by Lee et al. [23] as a data collection tool to measure the level of Moral decision-making by young athletes, Gürpınar [16] The Moral Decision-making Attitudes in the Building Sportsman were adapted to Turkish as a scale. The original study consisted of a 3 factor 9 items and a 5 point Likert type scale. On the original scale of 5 Likert type with three sub-dimensions, "I absolutely disagree" was rated as 1 point and "I strongly agree" as 5 points. It embraces the subscales of the scale (cheating if I think it will help me to win), adopting the liking of competition (sometimes trying to provoke rivalry) and protecting fairness (winning and losing is part of life). The subdimensions were decided to adopt tricks with items 1 and 5 of the scale, to adopt competition merit in items 2,4 and 6 , and to protect fairness with items 3,7 and 9 . Six positive negative $(1,2,4$, 5,6 , and 8 items) and 3 adjectives ( 3,7 , and 9 items) have positive meanings for measuring the moral decision-making attitudes. High scores from the scale were high in the moral decision-making attitudes of athletes; low scores mean that the athletic students' moral decision-making attitudes are at a low level. The validity of the three dimensions determined by the exploratory factor analysis was verified by confirmatory factor analysis in the adaptation process to Turkish and the fit goodness indices after the analysis were quite adequate (Chi-square / sd = $2.85, \mathrm{GFI}=.96, \mathrm{AGFI}=.93, \mathrm{CFI}=.96 ; \mathrm{NNFI}=.94 ;$ 
RMSEA $=.07$; SRMR $=.05$ ). Reliability study of the scale was performed with Cronbach Alpha internal consistency analysis. The Cronbach Alpha coefficient of the scale was .76 , and the reliability coefficient was .86 . When examining the subscales of the scale, it is seen that the internal consistency coefficients of the "Adopt cheer" sub-dimension .78, "Adopt competition affection" .68, "Maintain fairness" .59. In this research on "comparison of moral decision-making attitudes of elite male basketball players and wrestlers", the internal consistency coefficient of the moral decision-making attitude scale in Infrastructure sports is recalculated. As a result of this calculation, the total internal reliability coefficient was found to be .71 . When the reliability coefficients of the subscales of the scale were examined, it was calculated that "accept cheating" sub-dimension .78, "adoption of competition affinity" .61, "maintaining fairness" .74. Özdamar [26] determined the reliability coefficients between .81 and 1 as high and between .61 and .80 as the moderate reliability. It can be said that the sum of AMDYSQ and the sub-dimensions are at the middle level.

\section{Data Collection Process}

Research Malatya and Denizli in Turkey join the league to join the Basketball Championship Wrestling wrestler and basketball athletes are made to reaching. The study was conducted with volunteer sportsmen. Wrestlers' Moral Decision Making Attitudes Scale in Infrastructure Sports was applied in the gymnasium where the competition was held. Information on the purpose and application of the research to the athletes has been given. An example of how to respond to data collection tools to sports entities, has been shown since the information was transmitted. On average, the application was continued for 7 minutes and a total of 488 individuals were collected and removed from the study due to incomplete and incorrect marking of 13 data. The data of 475 people were checked and the process of analyzing the data entered in SPSS program was started.

\section{Statistical Analysis}

The data were analyzed using SPSS 21 statistical package program. In the analysis and evaluation of the data, normality analyzes and nonparametric analyzes were used in addition to using descriptive analyzes such as frequency, percentage, arithmetic mean, standard deviation. Prior to the analysis of the research data, it was tried not to identify possible outliers and extreme values that might be included in the researcher's dataset and affect the outcome of the research. Frequency distributions of the data are examined. After the review, it was understood that the data belonging to 5 persons were entered incorrectly in the SPSS program and these errors were corrected from the data analysis set. In addition, the $\mathrm{Z}$ values of the data of each individual were examined, the extreme values of the five data outside the range of +3 and -3 are checked and the data file is re-recorded. Kolmogorov-Smirnow and Shapiro-Wilk analyzes were performed to see if the data were normally distributed. According to Hair, Anderson, Tatham, \& Black [17], these two tests can be used for normality distribution. When the analysis results are examined, it is found that these tests are significant on the average score of the Moral Decision Making Attitudes Scale in Infrastructure Sports. The results of the Kolmogorov-Smirnow (t $(\mathrm{D} \quad(475)=.14, \mathrm{p}<0.01)$ Shapiro-Wilk test for the size of the trickery were found to be significant $(\mathrm{t}(\mathrm{D}(475)=.94, \mathrm{p}<.01)$. The results of the Kolmogorov-Smirnow ( $t$ (D $(475)=10, p<0.01$, Shapiro-Wilk test for the competitiveness dimension were found to be significant $(t(D)(475)=98, p<.01)$ For the winning dimension, the results of the Kolmogorov-Smirnow (t $(\mathrm{D} \quad(475)=15, \mathrm{p}<0.01)$, Shapiro-Wilk test were found to be significant According to Hair et al. [17] , the meaning of these analyzes means that the dataset is not normally distributed. In this study it is possible to say that the dataset does not show a normal distribution because the analysis results of Kolmogorov-Smirnow and Shapiro-Wilk tests are meaningful. At the same time, the research group of the Moral Decision Making Attitudes Scale in Infrastructure Sports An internal consistency analysis of Cronbach alpha was performed to analyze the reliability coefficient.

\section{Results}

The Mann Whitney-U test was used at this stage of the study to investigate the extent to which the sport moral decision-making attitudes were applied by the athletes and the factors that led to this hold. All variables are presented as mean, standard deviation, minimum and maximum values. Comparisons between basketball players and wrestlers are shown in Table 1, comparison with the duration of the sports experience, Table 2, and comparison with the educational levels of the parents are shown in Table 3 and Table 4. 
Table 1. Comparison of "Attitudes of Deciding Morally" between wrestlers and basketball players

\begin{tabular}{|c|c|c|c|c|c|c|c|c|}
\hline Sub-scales & Group & $\mathrm{N}$ & M & $\mathrm{SD}$ & Min. & Max. & $\begin{array}{c}\text { Mann } \\
\text { Whitney U }\end{array}$ & Asymp.Sig \\
\hline \multirow{3}{*}{$\begin{array}{l}\text { Acceptance of } \\
\text { cheating }\end{array}$} & Wrestlers & 280 & 10.18 & 3.34 & 3.00 & 15.00 & \multirow{3}{*}{25808.50} & \multirow{3}{*}{.31} \\
\hline & Basketball Players & 195 & 9.80 & 3.71 & 3.00 & 15.00 & & \\
\hline & Total & 475 & 10.02 & 3.49 & 3.00 & 15.00 & & \\
\hline \multirow{3}{*}{$\begin{array}{l}\text { Acceptance of } \\
\text { gamesmanship }\end{array}$} & Wrestlers & 280 & 9.09 & 2.96 & 3.00 & 15.00 & \multirow{3}{*}{22981.50} & \multirow{3}{*}{.00} \\
\hline & Basketball Players & 195 & 8.31 & 2.70 & 3.00 & 15.00 & & \\
\hline & Total & 475 & 8.77 & 2.88 & 3.00 & 15.00 & & \\
\hline \multirow{3}{*}{$\begin{array}{l}\text { Keeping winning in } \\
\text { proportion }\end{array}$} & Wrestlers & 280 & 10.03 & 3.84 & 3.00 & 15.00 & \multirow{3}{*}{19661.00} & \multirow{3}{*}{.00} \\
\hline & Basketball Players & 195 & 11.93 & 2.73 & 3.00 & 15.00 & & \\
\hline & Total & 475 & 10.81 & 3.55 & 3.00 & 15.00 & & \\
\hline
\end{tabular}

Wrestlers had higher a mean value in the variable of the acceptance of gamesmanship than basketball players. Conversely, basketball players showed higher average compare to wrestlers in the keeping winning in proportion. No significant difference was observed in the acceptance of cheating (Table 1).

Table 2. Comparison of "Attitudes of Deciding Morally" according to the duration of sport experience

\begin{tabular}{|c|c|c|c|c|c|c|c|c|}
\hline Sub-scales & Duration of Experience & $\mathrm{N}$ & M & $\mathrm{SD}$ & Min. & Max. & $\begin{array}{c}\text { Mann } \\
\text { Whitney U }\end{array}$ & Asymp.Sig \\
\hline \multirow{3}{*}{$\begin{array}{l}\text { Acceptance of } \\
\text { cheating }\end{array}$} & $1-10$ years & 371 & 9.85 & 3.48 & 3.00 & 15.00 & \multirow{3}{*}{16849.50} & \multirow{3}{*}{$.05^{*}$} \\
\hline & $11-20$ years & 104 & 10.62 & 3.52 & 3.00 & 15.00 & & \\
\hline & Total & 475 & 10.02 & 3.49 & 3.00 & 15.00 & & \\
\hline \multirow{3}{*}{$\begin{array}{l}\text { Acceptance of } \\
\text { gamesmanship }\end{array}$} & $1-10$ years & 371 & 8.66 & 2.79 & 3.00 & 15.00 & \multirow{3}{*}{17755.50} & \multirow{3}{*}{.21} \\
\hline & $11-20$ years & 104 & 9.14 & 3.16 & 3.00 & 15.00 & & \\
\hline & Total & 475 & 8.77 & 2.88 & 3.00 & 15.00 & & \\
\hline \multirow{3}{*}{$\begin{array}{l}\text { Keeping winning in } \\
\text { proportion }\end{array}$} & $1-10$ years & 371 & 10.69 & 3.57 & 3.00 & 15.00 & \multirow{3}{*}{17428.50} & \multirow{3}{*}{.13} \\
\hline & $11-20$ years & 104 & 11.24 & 3.46 & 3.00 & 15.00 & & \\
\hline & Total & 475 & 10.81 & 3.55 & 3.00 & 15.00 & & \\
\hline
\end{tabular}

$* \mathrm{P}<.05$.

Only the acceptance of cheating was only differentiated depending on the duration of experience. No significant difference was observed in the acceptance of gamesmanship and keeping winning in proportion depending on the duration of experience (Table 2).

Table 3. Comparison of "Attitudes of Deciding Morally" according to athletes' mother education level

\begin{tabular}{|c|c|c|c|c|c|c|c|c|}
\hline Sub-scales & $\begin{array}{c}\text { Education } \\
\text { Level }\end{array}$ & $\mathrm{N}$ & $\mathrm{M}$ & SD & Min. & Max. & $\begin{array}{c}\text { Mann } \\
\text { Whitney U }\end{array}$ & Asymp.Sig \\
\hline \multirow{3}{*}{$\begin{array}{l}\text { Acceptance of } \\
\text { cheating }\end{array}$} & $\begin{array}{l}\text { High School and } \\
\text { Under level }\end{array}$ & 413 & 10.15 & 3.43 & 3.00 & 15.00 & \multirow{3}{*}{10880.0} & \multirow{3}{*}{.06} \\
\hline & $\begin{array}{l}\text { Bachelor degree } \\
\text { and upper level }\end{array}$ & 62 & 9.16 & 3.82 & 3.00 & 15.00 & & \\
\hline & Total & 475 & 10.02 & 3.49 & 3.00 & 15.00 & & \\
\hline \multirow{3}{*}{$\begin{array}{l}\text { Acceptance of } \\
\text { gamesmanship }\end{array}$} & $\begin{array}{l}\text { High School and } \\
\text { Under level }\end{array}$ & 413 & 8.89 & 2.87 & 3.00 & 15.00 & \multirow{3}{*}{10166.5} & \multirow{3}{*}{$.01 * *$} \\
\hline & $\begin{array}{l}\text { Bachelor degree } \\
\text { and upper level }\end{array}$ & 62 & 7.97 & 2.80 & 3.00 & 15.00 & & \\
\hline & Total & 475 & 8.77 & 2.88 & 3.00 & 15.00 & & \\
\hline \multirow{3}{*}{$\begin{array}{l}\text { Keeping winning in } \\
\text { proportion }\end{array}$} & $\begin{array}{l}\text { High School and } \\
\text { Under level }\end{array}$ & 413 & 10.56 & 3.63 & 3.00 & 15.00 & \multirow{3}{*}{8862.0} & \multirow{3}{*}{$.00 * *$} \\
\hline & $\begin{array}{l}\text { Bachelor degree } \\
\text { and upper level }\end{array}$ & 62 & 12.50 & 2.40 & 4.00 & 15.00 & & \\
\hline & Total & 475 & 10.81 & 3.55 & 3.00 & 15.00 & & \\
\hline
\end{tabular}


The mean values of acceptance of gamesmanship and keeping winning in proportion were significantly differentiated depending on athletes' mother education level. But there was no significant difference with respect to athletes' mother education level of wrestlers and basketball players (Table 3).

Table 4. Comparison of "Attitudes of Deciding Morally" according to athletes' father education level

\begin{tabular}{|c|c|c|c|c|c|c|c|c|}
\hline Sub-scales & $\begin{array}{l}\text { Education } \\
\text { Level }\end{array}$ & $\mathrm{N}$ & M & $\mathrm{SD}$ & Min. & Max. & $\begin{array}{c}\text { Mann } \\
\text { Whitney U }\end{array}$ & Asymp.Sig \\
\hline \multirow{3}{*}{$\begin{array}{l}\text { Acceptance of } \\
\text { cheating }\end{array}$} & $\begin{array}{l}\text { High School and } \\
\text { Under level }\end{array}$ & 391 & 10.05 & 3.47 & 3.00 & 15.00 & \multirow{3}{*}{16027.000} & \multirow{3}{*}{.73} \\
\hline & $\begin{array}{l}\text { Bachelor degree } \\
\text { and upper level }\end{array}$ & 84 & 9.88 & 3.64 & 3.00 & 15.00 & & \\
\hline & Total & 475 & 10.02 & 3.49 & 3.00 & 15.00 & & \\
\hline \multirow{3}{*}{$\begin{array}{l}\text { Acceptance of } \\
\text { gamesmanship }\end{array}$} & $\begin{array}{l}\text { High School and } \\
\text { Under level }\end{array}$ & 391 & 8.92 & 2.88 & 3.00 & 15.00 & \multirow{3}{*}{13602.000} & \multirow{3}{*}{$.01 *$} \\
\hline & $\begin{array}{l}\text { Bachelor degree } \\
\text { and upper level }\end{array}$ & 84 & 8.08 & 2.80 & 3.00 & 15.00 & & \\
\hline & Total & 475 & 8.77 & 2.88 & 3.00 & 15.00 & & \\
\hline \multirow{3}{*}{$\begin{array}{l}\text { Keeping winning in } \\
\text { proportion }\end{array}$} & $\begin{array}{l}\text { High School and } \\
\text { Under level }\end{array}$ & 391 & 10.51 & 3.65 & 3.00 & 15.00 & \multirow{3}{*}{12046.500} & \multirow{3}{*}{$.00 * *$} \\
\hline & $\begin{array}{l}\text { Bachelor degree } \\
\text { and upper level }\end{array}$ & 84 & 12.20 & 2.68 & 4.00 & 15.00 & & \\
\hline & Total & 475 & 10.81 & 3.55 & 3.00 & 15.00 & & \\
\hline
\end{tabular}

$* \mathrm{P}<.05, * * \mathrm{P}<.01$

The mean values of acceptance of gamesmanship and keeping winning in proportion were significantly differentiated depending on athletes' father education level. But there was no significant difference with respect to athletes' father education level of wrestlers and basketball players (Table 4).

\section{Discussion}

Findings obtained in this part of the study were discussed with literature. The research result and the proposal are included in this section. When we look at the sub-dimension of adopting contest lover's moral decision-making attitudes between wrestlers and basketball players, the average value of adopting competition affinity in wrestlers is higher than basketball players. The literature on moral decision-making supports my research findings. For instance, Ponseti et al. [29] revealed that footballers are less interested in competitiveness and cheating in the study of contest loving and playing tricks on football, basketball and handball. Moreover, Fuster, Garda, Ponseti, Palou, Cruz [12] stated that the positive behaviors of coaches and referees in their work affected their competitiveness. As an individual sport, wrestling involves complex maneuvers in the fight against movements of the arms, legs and body against the opponent during a match. Wrestling also requires high-intensity intermittent workloads against rival reactions in attacks and contra-attacks. In this case, it can be inferred that the wrestlers' adoption of competition affinity is considerably higher than the basketball players since wrestlers like to fight with their opponents during the match. Similarly, basketball is a result of the collective effort of the team players who are fighting hard due to the tempos of the game. On the other hand, offense and defense depends only on the individual effort of the athlete.

In our study, it was revealed that basketball players had a higher average to protect fair winners from wrestlers. Gürpınar [16] stated that when the rate of sport contact increased and antisocial behaviors also increased. Upton [33] reported that attitudes toward deception related to the sport branch were a component of the game. It causes antisocial attitudes such as the type and amount of the oppression or the conditions of the playing environment, the acceptance of the frailty and the lack of love of competition. Gürpınar [16] explains the interesting difference in moral decision-making between volleyball and soccer by dividing sports into non-contact and contact sports. Lee et al. [13] reported that the mean values for team athletes' moral decision-making attitudes were lower than for individual sportsmen. These results are inconsistent with the results of our sub-dimension of fair win-win. In our work, wrestlers have a lower average than just gaining justice. Another reason why wrestlers have a low average of basketball players in protecting fair winnings can be thought of as a result of high intensity struggle during the match. There was no significant difference between the basketball player and the wrestlers in terms of adopting the trick in the research. Zengaro, Chester [36] stated that the acceptance of aggression has changed the variables of cheating and fairness by adopting the liking of competition and preserving fairness. Tactics to adopt fairness adopt tricks and admit competition merit, while at sport affects aggression negatively, affects at sport 
aggression positively. Moreover, Tucker \& Parks [32] study is based on the physical dominance of an athlete against another and the aggressive behavior is lower in contact and non-contact sports compared to individual or team sports, where the athletes use their bodies to deter or obstruct their opponents. Aggression can lead to unethical behavior in sporting events. The tendency to aggression differs according to the level of experience in our work, while the tendency to aggression is mostly in the educational level of the parents in the variables of protecting the fairness by adopting the admiration of competitiveness. Due to the duration of sport experience, acceptance of cheating has changed. Depending on the duration of the Sport Experience, there is no significant difference in terms of fairness in winning and in respect of adopting competition severity. The sport experience is about how many years you have been doing sports, what kind of sport you are doing and what level you are as a competitor. In our study, only significant changes were observed in the adoption of the cheating, depending on the duration of experience. The duration of experience does not seem to be effective in the adoption of competition favors and protecting fairness. On the other hand, Shields et al. [31] reported that, in high-level encounters with high school male baseball players and female softballs, men are generally expected to exhibit fraudulent and aggressive behavior in elderly and highly experienced athletes. In addition, the same researchers have shown that there is a positive relationship between playing in the winning team and high-ranking cheating expectant. Kavussanu, Seal, Phillips [20] compared the anti-social behaviors of the 3 -year-old group of 13,15 and 17 year old participants and reported that social behaviors decreased with increasing age. On the contrary, anti-social behavior is increasing with age. Kaye \& Ward [19] reported an increase in the adoption of the dolls up to the categories of teenagers and elders in newly started athletes. In addition, Lee et al. [23] reported that adoption of age and admission of competition severity was higher in elderly athletes than in young people. The increase was also observed with the increase in the level of competitiveness of aggression [6]. These increases are strongly related to the duration of experience and the increased appreciation of achievements in high-level competitions. Older or more experienced competitor student athletes may come to the conclusion that their teams have gone to anti-social behavior for success. The average values in terms of adopting competitiveness and protecting fairness differ markedly from that of the athletes' parents. However, wrestlers and basketball players have no significant difference in adoption according to parental education levels. Dishion \& Patterson [8] stated that children's behaviors are exhibited, learned, encouraged and suppressed in the basic environment created in the family environment. Using the behaviors, rules and discipline of parents in the family environment, children are preparing for adulthood. Palou, Ponseti, Cruz, Vidal \&
Cantallops [27] the relative environment created by the coach is related to cheating and racing at a high level by the trainer's ego-oriented environment when there is no connection with cheating and competition, and that the motivational environment created by the family is not about accepting fraud and competition.

In addition, Huisman and Smits [18] reported that mothers with more knowledge had a strong positive effect on their children's education. In Turkey, the athletes 'current stance of moral decision-making was planned in order to uncover fair competition with the adoption of variable gain protection average values differed significantly according to the athletes' parents and educational level. However, the educational level of parents of wrestlers and basketball players is not an effect on the acceptance of cheating. Bandura, Grusec, Menlove [1] reported that children observe behavior patterns and standards not only in their parents but also in their siblings, peers, and other adults. If the athlete considers approving the unethical behavior of his teammate or best friend; they will be more likely to engage in such negative behavior. According to Bandura's Social Learning Theory [2] it is reasonable to say that athletes learn by interacting with social groups such as cheating, aggression and other anti-social behavior, teammates and coaches. Although the parents of the family prepare their children for adulthood using their behaviors, rules and discipline, the athletes learn and accept team norms throughout the sport life. Each sporting environment is unique and different. This means that differences arising from the sport environment may cause the anti-social behaviors related to the subject to be differentiated. In conclusion, in this study, it can be concluded that the adoption of cheating does not depend on the type of sports, as it depends on the sporting experience, the effect of adopting the competitiveness of competition and changing the fairness to gain subparts according to the parental education and sports branch. Future research in this area can be designed to investigate the relationship between ethical decision-making attitudes and socio-economic levels in different levels of competition and sports, in terms of variables to protect fairness by adopting cheating and competition.

\section{REFERENCES}

[1] Bandura, A., Grusec, J. E. ve Menlove, F. L. (1967). Some social determinants of self-monitoring reinforcement systems. Journal of Personality and Social Psychology, 5(4), 16-23.

[2] Bandura, A. (1977). Social learning theory. General Learning Press. 305-316.

[3] Begg, D. J., Langley, J. D., Moffitt, T. ve Marshall, S. W. (1996). Sport and delinquency: An examination of the deterrence hypothesis in a longitudinal study. British 
Journal of Sport Medicine, 30(4), 335-341.

[4] Borg W. R. \& Gall, M. D. (1989). Educational research. New York: Logman

[5] Büyüköztürk, Ş., Kılıç, E. K., Akgün, Ö. E. Karadeniz, Ş. \& Demirel, F. (2009). Bilimsel Araştırma Yöntemleri, 3. Bask1, Ankara: Pegem Akademi Yayınlar1.

[6] Coulomb - Cabagno, G. \& Rascle, O. (2006). Team sports players' observed aggression as a function of gender, competitive level, and sport type. Journal of Applied Social Psychology, 36(8), 1980-2000.

[7] Cruz, J., Capdevila, L., Boixadós, M., Pintanel, M., Alonso, C., Mimbrero, J. \& Torregrosa, M. (1996). Identificación de conductas, actitudes y valoresrelacionadoscon el Fairplay en Deportistas Jóvenes. En Valores Sociales y Deporte: Fairplayversus Violencia. (pp. 38-67).

[8] Dishion, T.J., \& Patterson, G.R. The development and ecology of antisocial behavior in children and adolescents. In Developmental Psychopathology; Wiley: Hoboken, NJ, USA, 2006; Volume 3, pp. 503-541.

[9] Duda, J. L., Olson, L. K. \& Templin, T. J. (1991). The relationship of task and ego orientation to sportsmanship attitudes and the perceived legitimacy of injurious acts. Research Quarterly for Exercise and Sport, 62(1), 79-87.

[10] Erkal, M., Güven, Ö., \& Ayan, D., Sosyolojik Açıdan Spor, Der Yayınları, 1998.

[11] Fraenkel, J. R., \& Norman, E. W. (2006). How to design and evaluate research in education. McGraw-Hill: Boston.

[12] Fuster-Parra, P., Garda-Mas, A., Ponseti, F. J., Palou, P. \& Cruz, J. (2014). A Bayesian network to discover relationships between negative features in sport: a case study of teen players. Quality \& Quantity, 48(3), 1473-1491.

[13] Gardner, M., Roth, J. \& Brooks-Gunn, J. (2009). Sports Participation and Juvenile Delinquency: The Role of the Peer Context among Adolescent Boys and Girls with Varied Histories of Problem Behavior. Developmental Psychology, 45(2), 341-353.

[14] Guivernau, M. \& Duda, J. L. (2002). Moral atmosphere and athletic aggressive tendencies in young soccer players. Journal of Moral Education, 31(1), 67-85.

[15] Güngör, E. (2000). Ahlak Psikolojisi ve Sosyal Ahlak, Ötüken Yayıncılık, İstanbul.

[16] Gürpınar, B. (2014). Sporcu Ortaokul ve Lise Öğrencilerinin Spora Ait Değişkenler Açısından Ahlaki Karar Alma Tutumları, Eğitim ve Bilim, 39(176): 413-424.

[17] Hair, J.F. Jr., Anderson, R.E., Tatham, R.L., \& Black, W.C. (1998). Multivariate Data Analysis, (5th Edition). Upper Saddle River, NJ: Prentice Hall.

[18] Huisman, J., \& J. Smits, 2009. "Effects of Household- and District- level factors on Primary School Enrolment in 30 Developing Countries". World Development, 37(1): 179-193.

[19] Kaye, M. P. \& Ward, K. P. (2010). Participant-related differences in high school athletes' moral behavior. Athletic Insight: The Online Journal of Sport Psychology, 12(1), $1-17$.
[20] Kavussanu, M., Seal, A. R. \& Phillips, D. R. (2006). Observed prosocial and antisocial behaviors in male soccer teams: Age differences across adolescence and the role of motivational variables. Journal of Applied Sport Psychology, 18(4), 326-344.

[21] Kırımoğlu H., Parlak N., \& Dereceli Ç. (2008). Lise Öğrencilerinin Saldırganlık Düzeylerinin Spora Katılım Düzeylerine Göre İncelemesi, Niğde Üniversitesi Beden Eğitimi ve Spor Bilimleri Dergisi Cilt2, Say12.

[22] Koul, R. (2012). Multiple motivational goals, values, and willingness to cheat. International Journal of Educational Research, 56, 1-9.

[23] Lee, M. J., Whitehead, J. \& Ntoumanis, N. (2007) Development of the attitudes to moral decision-making in youth sport questionnaire (AMDYSQ). Psychology of Sport and Exercise, 8(3), 369-392.

[24] Lee, M. J., Whitehead, J., Ntoumanis, N., \& Hatzigeorgiadis, A. (2008). Relationships among Values, Achievement Orientations, and Attitudes in Youth Sport. J. Sport Exerc. Psychol. 30, 588-610.

[25] Mavi S, Tuncel S.D. (2012). Sporcuların Sporda Hoşgörü Kavramına İlişkin Algıları, SPORMETRE Beden Eğitimi ve Spor Bilimleri Dergisi, 10 (4): 125-129.

[26] Özdamar, K. (1999) Paket Programlar İle İstatistiksel Veri Analizi1. Kaan Kitabevi, Eskişehir

[27] Palou, P., Ponseti, F. J., Cruz, J., Vidal, J., Cantallops, J., Borras, P. A. \& Garcia-Mas, A. (2013). Acceptance of Gamesmanship and Cheating In Young Competitive Athletes In Relation To the Motivational Climate Generated By Parents and Coaches. Perceptual \& Motor Skills, 117(1), 290303.

[28] Pehlivan Z. (2004). Fair-Play Kavramının Geliştirilmesinde Okul Sporunun Yeri ve Önemi, SPORMETRE Beden Eğitimi ve Spor Bilimleri Dergisi, 2 (2): 49-53.

[29] Ponseti, F. J., Palou, P., Borràs, P. A., Vidal, J., Cantallops, J., Ortega, F., Boixados, M., Sousa, C., Garcia-Calvo, T. \& Garcia-Mas, A. (2012). El Cuestionario de Disposición al Engaño en el Deporte (CDED): su aplicación a jóvenes deportistas. Revista de Psicología del Deporte, 21(1), 75-80.

[30] Roig M., \& Ballew C. (1994) Attitudes toward Cheating of Self and Others by College Students and Professors. The Psychological Record 44: 3-12

[31] Shields, D. L., \& Bredemeier, B. L. (2007). "Advances in sport mortality research," in Handbook of Sport Psychology, eds G. Tenenbaumand R. C. Eklund (New York, NY: JohnWiley), 662-684.

[32] Tucker, L. W. \& Parks, J. B. (2001). Effects of gender and sport type on intercollegiate athletes' perceptions of the legitimacy of aggressive behaviors in sport. Sociology of Sport Journal, 18(4), 403-413.

[33] Upton, H. (2011). Can there be a Moral Duty to Cheat in Sport? Sport, Ethics and Philosophy, 5(2), 161-174.

[34] Yoncalık O, Gündoğdu C. (2007). Sporda Ahlaki Bir Sorun Olarak Doping, Doğu Anadolu Bölgesi Araştırmaları.

[35] Weiss, M. R. \& Bredemeier, B. J. L. (1990). Moral development in sport. Exercise and sport sciences reviews, 
18(1), 331-378.

[36] Zengaro, F, \&. Chester, F. (2010, March). Making a Difference Coaching One Athlete at a Time. Paper presented at the meeting of the National Youth-At-Risk Conference.
Savannah, GA.

[37] Ziyagil, M.A, Bilir, P.,Çekin R., \& Temur C.S. (2014) Türkiye'de Sporda Saldırganlık, Şiddet ve Çözüm Önerileri, CBÜ Beden Eğitimi ve Spor Bilimleri Dergisi 7(1).

${ }^{\mathrm{i}}$ This study was presented in the ERPA International Congress on Education, p.87, held in June, 02-04, 2016, Sarajevo in Bosnia and Herzegovina. 